\title{
TERMÉSZETES ÉS MESTERSÉGES VÁROSI BURKOLATOK FELSZÍNHŐMÉRSÉKLETI VISZONYAI BUDAPEST XI. KERÜLETÉBEN
}

\author{
Dezső Zsuzsanna $^{(1)}$ (D), Bartholy Judit ${ }^{(1,2)}$ (D), Pongrácz Rita ${ }^{(1,2)}$ \\ (1) ELTE Meteorológiai Tanszék, 1117 Budapest, Pázmány Péter sétány 1/A \\ (2) ELTE TTK Kiválósági Központ, 2462 Martonvásár, Brunszvik u. 2. \\ e-mail: dezsozsuzsi@caesar.elte.hu,bartholy@caesar.elte.hu,prita@nimbus.elte.hu
}

\section{Bevezetés}

Mivel ma már a világ népességének több mint fele, Magyarország lakosságának pedig közel háromnegyede városokban él $\mathrm{KSH}^{1}$, ezért egyre nagyobb hangsúlyt kap az épített környezet éghajlatmódosító hatásainak vizsgálata. A települések területén kialakuló sajátos éghajlati viszonyokat összefoglalóan városklímának nevezzük. Ennek egyik legjellegzetesebb megjelenési formája a városok területén fellépő hőmérsékleti többlet, a városi hősziget.

A hőtöbblet kialakulásának alapja az emberi tevékenység: a mesterséges anyagok, burkolatok használata, a jellegzetes városi geometria, az aktív sugárzási felszínek nagy aránya, a csökkent égboltláthatóság és a felszín érdessége, valamint az antropogén hö- és szennyezöanyag-kibocsátás következtében a sugárzási egyenleg egyes komponenseinek az aránya megváltozik, ami számos esetben a hőmérséklet emelkedését eredményezi (Oke, 1982). E hőtöbbletnek az emberek komfortérzetére gyakorolt hatása függ az adott település földrajzi elhelyezkedésétől és az évszaktól is. A téli időszakban, illetve a hüvösebb éghajlatú városokban a hősziget-hatás akár előnyökkel is járhat: csökkennek a fütési költségek, ritkábban alakul ki köd, a hótakaró általában vékonyabb és rövidebb ideig marad meg, mint a városkörnyéki területeken, és az utcán tartózkodó emberek szubjektív komfortérzete is kedvezőbb. Ezzel szemben a meleg évszakban, illetve a forró nyarakkal jellemezhető városokban e hőtöbblet többnyire hátrányokkal jár együtt. A szabadban tartózkodó emberek sokszor extrém höstressznek vannak kitéve, nő az ezzel összefüggésbe hozható halálesetek, megbetegedések száma, és a légkondicionálás müködtetéséhez szükséges energiaigény is fokozódik (Stewart \& Oke, 2012).

A városi hősziget-hatás hazánk éghajlati adottságai mellett a nyári időszakban egyértelmüen negatív következményekkel jár együtt. A meleg évszak éghajlatát jól jellemzik a különféle extrém hőmérsékleti klímaindexek. Ezen indexek egyik csoportja az egy adott hőmérsékleti küszöbértéket meghaladó maximum hőmérsékletű napok éves számát adja meg. Az 1981-2000 referencia időszakban a Carpatclim adatbázis (Szalai et al., 2013) alapján az indexek országos átlagos értékei a következőképpen alakultak: a nyári napok száma $\left(\mathrm{T}_{\max }>25^{\circ} \mathrm{C}\right) 75$ nap/év, a hőségnapok száma $\left(\mathrm{T}_{\max }>30^{\circ} \mathrm{C}\right) 20$ nap/év, a forró napok száma $\left(\mathrm{T}_{\max }>35^{\circ} \mathrm{C}\right) 12$ nap/évtized volt (Pieczka et al., 2018). A hösziget-hatás következtében városi környezetben ezek száma jelentős mértékben emelkedik. Például Közép-Európa nagyvárosainak belvárosában a nyári napok évi átlagos száma az 1981-2010 közötti időszakban meghaladta a 100-140 napot (Bokwa et al., 2018). Számos kutatás alátámasztja, hogy a jövőben az éghajlatváltozás következtében ez az érték tovább fog emelkedni, az éghajlati modellek becslései alapján az évszázad végére Magyarországon a jelenlegihez képest évente átlagosan 40-50 nappal több nyári, hőség- és forró nap várható (Bartholy et al., 2011; Pongrácz et al., 2016).

\footnotetext{
${ }^{1}$ KSH: https://www.ksh.hu/docs/hun/xstadat/xstadat_eves/__wdsd001.html
} 
A városi környezetben megjelenő kedvezőtlen éghajlati hatások megismerése és mérséklési lehetőségeinek vizsgálata céljából néhány éve egy hosszútávú együttmüködés jött létre az ELTE Meteorológiai Tanszéke és Újbuda Önkormányzatának Környezetvédelmi Osztálya között, melynek keretében az elmúlt években több mérési programot is megvalósítottunk a kerületben (Dezső et al., 2018). 2018 nyarán egy olyan méréssorozatot kezdtünk el, melynek célja annak vizsgálata, hogy a különféle városi felszínt borító anyagok, burkolatok milyen hőmérsékleti tulajdonságokkal rendelkeznek, és milyen mértékben járulnak hozzá a hőszigethatás fokozódásához.

\section{A mérési program bemutatása}

Újbuda a föváros legnépesebb kerülete, fontos kereskedelmi, közlekedési csomópontok, sürün beépített gazdasági és lakóövezetek találhatóak itt, ugyanakkor bizonyos városrészek laza, kertvárosi beépítésűek, és viszonylag nagy arányban fordulnak elő parkok, erdők is. A kerületben két helyszínen végeztünk méréseket, a rendkívül forgalmas Móricz Zsigmond körtéren és egy zöldebb területen: a Bikás Parkban. Vizsgálataink során különféle anyagok, tereptárgyak felszínhőmérsékletét mértük meg egy Voltcraft IR-280 típusú infrahőmérő segítségével. A Móricz Zsigmond körtéren összesen 17, a Bikás Parkban 37 mérési pontot jelöltünk ki. A mérési pontok pontos elhelyezkedését és a 2018. nyári mérések elsődleges eredményeit egy korábbi tanulmányunkban (Dezső et al., 2018) már bemutattuk.

Jelen elemzésben: (i) a 2018. július 2. és 5. között, (ii) a 2019. május 17-én, (iii) május 23. és 26. között, valamint (iv) június 6-án és 7-én végzett méréseinek részletes elemzését ismertetjük. A 2018-as mérések során napi négy alkalommal, délelőtt 9:00-10:00 között, kora délután 13:00-14:00 között, késő délután 17:00-18:00 között és este 21:00-22:00 óra között végeztünk felszínhőmérsékleti méréseket a kijelölt mérőpontokon, míg a 2019-es mérési napokon napi három mérés történt, délelőtt 8:00-9:00 között, délben 12:00-14:00 között és este 18:00-20:00 között. A mérőpontok többségénél - ahol ez megoldható volt - nappal, napsütéses időben mind az adott felület direkt napsugárzásnak kitett részének, mind az árnyékos részének a felszínhőmérsékletét rögzítettük, így az árnyékolás hőmérséklet-mérséklő szerepét is vizsgálni tudtuk.

\section{Vizsgálati eredmények}

A legmagasabb felszínhőmérsékleteket értelemszerüen a legnagyobb napmagasság idején, a déli, kora délutáni időszakban mértük. Az 1. és a 2 ábra rendre a Bikás parkban, illetve a Móricz Zsigmond körtéren az összes rendelkezésre álló mérésünkből a déli időszakban mért átlagos felszínhőmérsékleti értékeket mutatja be. A grafikonok felső része a közvetlen napsugárzásnak kitett felületek, míg az alsó része az árnyékos felületek átlagos felszínhőmérsékletét mutatja be. A különféle felszínanyagokat különböző színekkel jelöltük. Látható, hogy a Bikás parkban a vízfelület a leghidegebb, továbbá a hüvösebb felületek közé tartoznak a növényzettel borított felszínek és a fémfelületek. A beton- és aszfaltburkolatok napsugárzásnak kitett részeinek a vizsgált napokra vonatkozó átlagos felszínhőmérséklete meghaladta a $30^{\circ} \mathrm{C}$-ot, a festett fafelületek és a gumiburkolattal borított felszíneké pedig akár a $40{ }^{\circ} \mathrm{C}$-ot is. Az árnyékos felületek esetében a beton felületek a legmelegebbek, ezek átlagos felszínhőmérséklete $30^{\circ} \mathrm{C}$ körül alakult. Ha a napos és árnyékos felületekre vonatkozó mérési adatokat összevetjük, megállapíthatjuk, hogy a napsugárzásnak kitett felületek minden esetben melegebbek, mint az árnyékosak, de a napsugárzásnak való kitettség az egyes anyagok vonatkozásában eltérő mértékü különbségeket eredményez. A beton felületek, térkövek esetében mind az árnyékos, mind a napos értékek viszonylag magasak, ezzel szemben a gumiburkolatok esetén az árnyékolt felületek nem melegszenek fel jelentős mértékben (átlag- 
hőmérsékletük $20-30{ }^{\circ} \mathrm{C}$ között alakul), viszont a napsugárzásnak kitett felszínek extrém mértékben felmelegszenek.

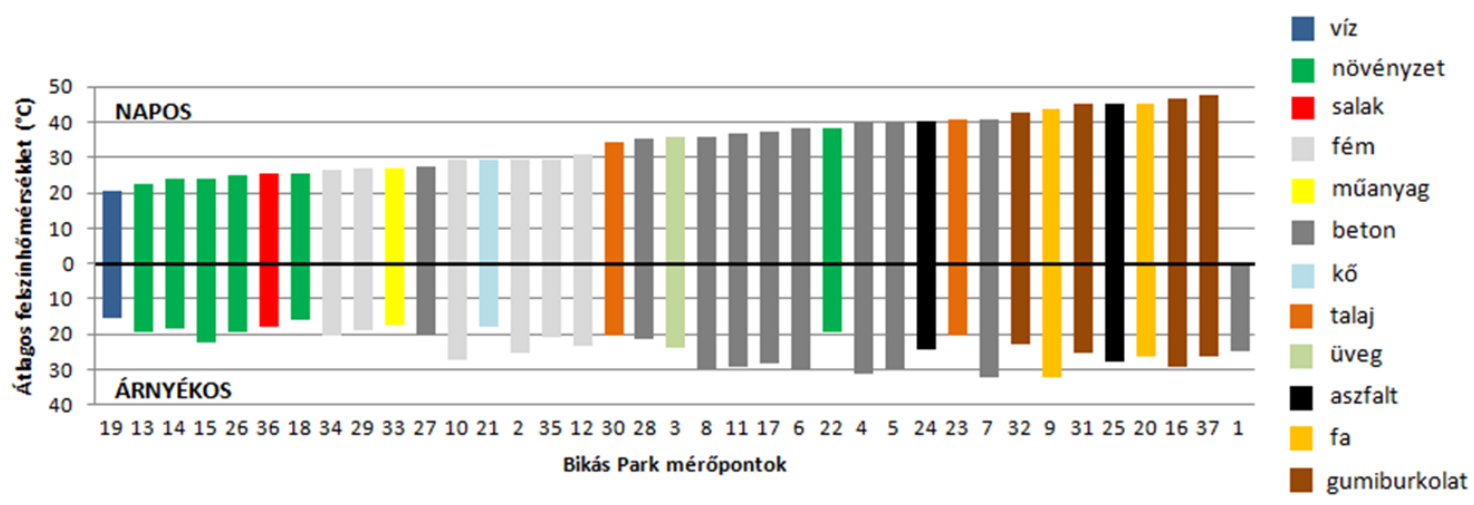

1. ábra: A Bikás parki mérőpontokon mért átlagos felszínhőmérséklet a déli időszakban.

A színek a mérőpontok felszínének anyagát jelzik. A diagram felső része (pozitív irány) az adott pontnak a direkt napsugárzásnak kitett, míg az alsó része (negatív irány) az árnyékos felületek átlagos déli felszínhőmérsékletét mutatja be.

A Móricz Zsigmond körtéren szintén a vízzel és növényzettel borított felszínek a leghüvösebbek, a beton és aszfaltfelületek a legmelegebbek, utóbbiak átlagos felszínhőmérséklete árnyékos esetben $30{ }^{\circ} \mathrm{C}$ körül, a napsütésnek kitett felületek esetében pedig $40{ }^{\circ} \mathrm{C}$ felett alakul.

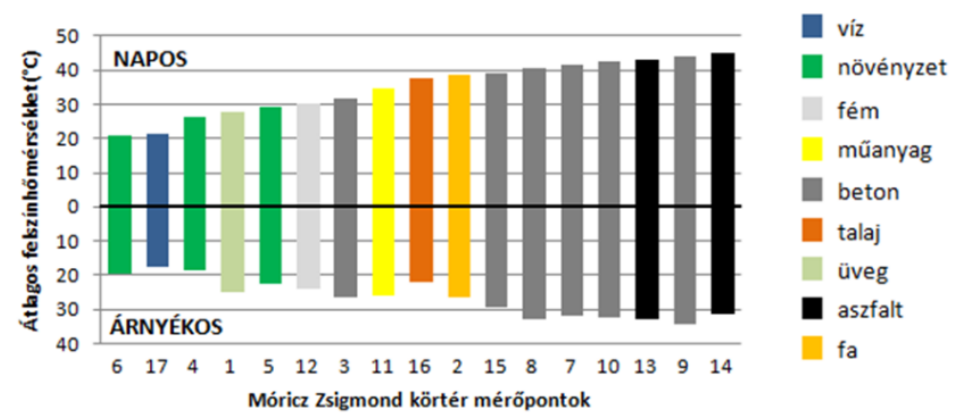

2. ábra: A Móricz Zsigmond körtéri mérőpontokon mért átlagos felszínhőmérséklet a déli időszakban.

A színek a mérőpontok felszínének anyagát jelzik. A diagram felső része (pozitív irány) az adott pontnak a direkt napsugárzásnak kitett, míg az alsó része (negatív irány) az árnyékos felületek átlagos déli felszínhömérsékletét mutatja be.

A felszín anyaga mellett annak színének a felszínhőmérséklet alakulására gyakorolt hatását is megvizsgáltuk a gumiburkolatok (Bikás park) és a beton térkövek (Móricz Zsigmond körtér) esetében. A 3. ábra ún. box-whiskers diagram segítségével mutatja be négy gumiburkolatú felszín összes felszínhőmérsékleti értékének eloszlását. A B31-es méröpontot szürke, a B32-est és B16-ost piros, a B37-est pedig kék színü burkolat borítja. Mivel a napsugárzásnak kitett felületeken a legtöbb esetben magasabb értékeket mértünk, mint az árnyékolt felületeken, így a medián feletti tartomány jórészt a napos, míg az az alatti az árnyékos méréseket reprezentálja. A diagramok aszimmetriája arra utal, hogy a napsugárzásnak közvetlenül kitett méréseknek nagyobb a szórása, mint az árnyékos méréseké. Az árnyékos méréseknél kisebb a jelentősége a színeknek, amit az is jól mutat, hogy a minimumok és az alsó 
kvartilisek között kisebb a különbség az egyes mérőpontok között, mint a napos méréseket reprezentáló maximumok és a felső kvartilisek esetében.

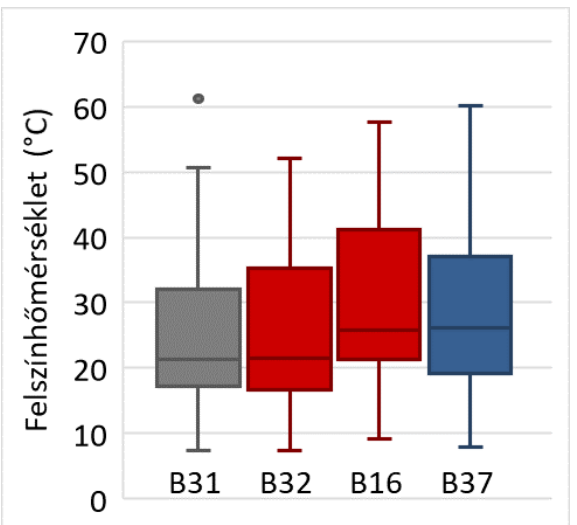

3. ábra: A Bikás Parkban található gumiburkolatú mérési pontok felszínhőmérsékletének eloszlása.

A box-whiskers diagramon az alsó és felső vonal a mérőpont adatsorának minimumát és maximumát, míg a téglalap alsó és felső éle annak alsó és felső kvartilisét jelzi.

A téglalapban található vízszintes vonal jelöli az adatsor medián értékét.

A mérőpontok burkolatának színe: B31 - szürke, B32 - piros, B16 - piros, B37 - kék.

A 4. ábra szintén box-whiskers diagramon mutatja be a Móricz Zsigmond körtéren található beton burkolatok felszínhőmérsékleti adatainak eloszlását. Az M15-ös pontot világosszürke, az M10-est sötétszürke, az M8-ast piros, az M9-est pedig kék térkö borítja. Az adatsorok összes mérésből számított medián értéke $26-27{ }^{\circ} \mathrm{C}$ körül alakul az összes szín esetében. A felső kvartilisek és a maximumok között viszont már sokkal nagyobb különbség tapasztalható: míg a felső kvartilisek $34^{\circ} \mathrm{C}$ és $39^{\circ} \mathrm{C}$ között, addig a maximumok $45^{\circ} \mathrm{C}$ és $50^{\circ} \mathrm{C}$ között alakulnak. Ha a medián és a felső kvartilis alapján rendezzük sorba az egyes színekhez tartozó adatsorokat, akkor megállapíthatjuk, hogy a kék térkő esetében fordulnak elő a legmagasabb hőmérsékleti értékek. A maximum értékek között viszont a sötétszürke burkolat esetében fordul elő a legmagasabb - akár $50^{\circ} \mathrm{C}$-ot is meghaladó - hőmérsékleti érték. Összességében megállapíthatjuk, hogy a burkolatok színe különösen a napsugárzásnak kitett felületek esetén befolyásolja az adott felület felszínhőmérsékletét. Ennek oka az, hogy a világosabb felületek nagyobb albedóval rendelkeznek, azaz a beérkező napsugárzás nagyobb részét verik vissza, így a sugárzás energiájának csak kisebb hányada fordítódik a felület felmelegítésére.

Az 5. ábra a Bikás parkban található gumiburkolatú felületek felszínhőmérsékleti értékeit mutatja be részletesen az összes mérési időpontra vonatkozóan. A körök a napos, a keresztek az árnyékos mérések értékeit jelölik. Fontos megjegyezni, hogy borult időben, illetve az esti mérési időpontban csak árnyékos mérések állnak rendelkezésre. A részletes elemzéshez azért választottuk ki ezeket a mesterséges burkolati típusokat, mivel napjainkban ez a játszóterek, sportolási célú létesítmények kialakításánál az egyik legnépszerübb burkolóanyag, amit általában gumiőrlemény és poliuretán keverékéből állítanak elő (a közbeszédben gyakran rekortánnak nevezik). A teljes mérési időszakban 2018. július 3-án mértük a legmagasabb felszínhőmérsékletet, a szürke felületü gumiburkolat (B31) hőmérséklete $61,2{ }^{\circ} \mathrm{C}$ volt! A diagramon jól elkülönülnek az árnyékos és a napos mérések. Míg az árnyékos értékek napszaktól függöen $10{ }^{\circ} \mathrm{C}$ és $40{ }^{\circ} \mathrm{C}$ között alakulnak, addig a napsugárzásnak kitett felszínek hőmérséklete sokszor már a reggeli órákban meghaladja a $30^{\circ} \mathrm{C}$-ot, a déli, kora délutáni órákban pedig 40-60 ${ }^{\circ} \mathrm{C}$ körül alakul. A rendkívül magas felszínhőmérsékletek hatására a felszínközeli légrétegek is extrém módon felforrósodnak, így a gumiburkolattal borított létesítmények pl.: játszóterek, futópályák, sportpályák - nyáron a nappali időszakban szinte teljesen használ- 
hatatlanná válnak az ott-tartózkodókat érő rendkívüli hőterhelés miatt. Ugyanakkor vizsgálataink rávilágítanak arra, hogy természetes és mesterséges árnyékolók használatával jelentős mértékben csökkenthető a gumiburkolatú felszínek hőmérséklete: ezáltal a nyári kritikus időszakban sem éri akkora extrém hatás a sportolni vágyókat, s különösen az érzékenyebbnek tekinthető kisgyerekeket.

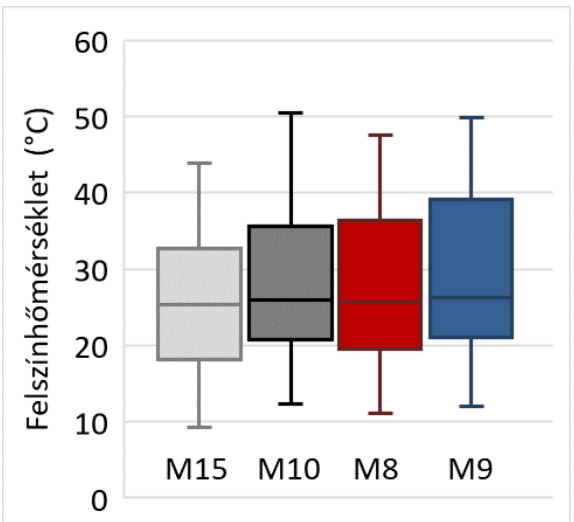

4. ábra: A Móricz Zsigmond körtéren található beton térkő burkolatú mérési pontok felszínhőmérsékletének eloszlása. A box-whiskers diagramon az alsó és felső vonal a mérőpont adatsorának minimumát és maximumát, míg a téglalap alsó és felső éle annak alsó és felső kvartilisét jelzi. A téglalapban található vízszintes vonal jelöli az adatsor medián értékét. A mérőpontok burkolatának színe: M15 - világosszürke, M10 - sötétszürke, M8 - piros, M9 - kék.

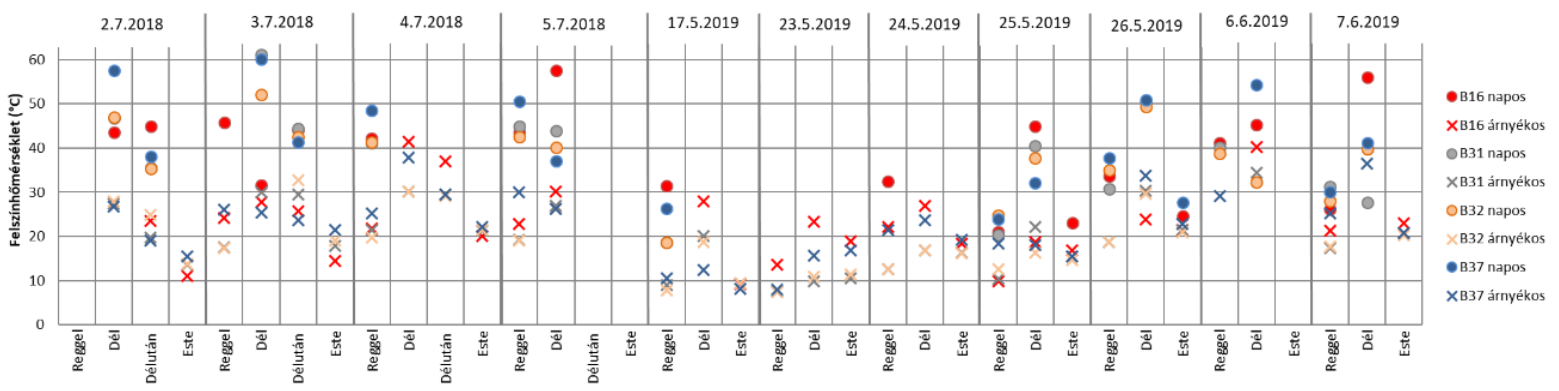

5. ábra: A Bikás Parkban található gumiburkolatú mérési pontokon mért felszínhőmérsékleti értékek. A körök a napos, a keresztek az árnyékos felületek hömérsékleti értékeit jelölik. A mérőpontok burkolatának színe: B31 - szürke, B32 - piros, B16 - piros, B37 - kék.

\section{Összefoglalás}

2018 júliusában, valamint 2019 májusában és júniusában a hallgatóink bevonásával felszínhőmérsékleti méréseket végeztünk Budapest XI. kerületében, a Bikás park és a Móricz Zsigmond körtér környékén. A mérések eredményei azt mutatják, hogy a késő tavaszi, kora nyári időszakban jelentős hőmérséklet-különbség alakul ki a direkt napsugárzásnak kitett és az árnyékos felületek között. Városklimatológiai szempontból a természetes felszínek, s a növényzettel vagy vízzel borított felületek rendelkeznek a legkedvezőbb termikus tulajdonságokkal. A legmagasabb hőmérsékleteket a napsugárzásnak közvetlenül kitett gumiburkolatok, aszfalt- és betonfelületek esetében mértük, ezek felszínhőmérséklete kora délután sokszor a $40-50{ }^{\circ} \mathrm{C}$-t is meghaladta. Vizsgálataink rávilágítottak a világosabb színek alkalmazásának és az árnyékolásnak a fontosságára is.

A megfelelő burkolóanyagok és színek megválasztásával, a természetes felszínek (növényzet, víz) arányának növelésével, árnyékolással hatékonyan mérsékelhető a felszín hőmérsék- 
lete, ami alapvetően meghatározza a felszínközeli légrétegek hőmérsékleti viszonyait is. Ezáltal az emberi hőérzet szempontjából kedvezőbb körülmények alakíthatók ki, ami elősegítheti a komfortosabb, egészségesebb és élhetőbb városok létrejöttét.

\section{Köszönetnyilvánítás}

Kutatásainkat az OTKA K-120605 és K-129162 számú projektje, az Európai Regionális Fejlesztési Alap Széchenyi 2020 programja az AgroMo projekt (GINOP-2.3.2-15-2016-0028) keretében, az Emberi Erőforrások Minisztériuma az ELTE Kiválósági Program (projektszám: 783-3/2018/FEKUTSRAT) keretében, valamint az MTA Bolyai János Kutatási Ösztöndíja támogatta. A helyszíni mérések elvégzéséért köszönet Berényi Alexandra, Dávid Réka, Incze Dóra, Nagy Domonkos, Rumpler Dániel, Szalai Viktor, Topál Dániel és Tóth Anita egyetemi hallgatóknak.

\section{Hivatkozások}

Bartholy, J., Bozó, L., Haszpra, L. (szerk.), 2011: Klímaváltozás - 2011: Klímaszcenáriók a Kárpát-medence térségére. Magyar Tudományos Akadémia, Eötvös Loránd Tudományegyetem Meteorológiai Tanszéke. Budapest, 281p.

Bokwa, A., Dobrovolny, P., Gal, T., Geletic, J., Gulyas, A., Hajto, M. J., Holec, J., Hollósi, B., Kielar, R., Lehnert, M., Skarbit, N., Stastny, P., Švec M., Unger, J., Walawender, J.P.,Žuvela-Aloise, M., 2018: Urban climate in Central European cities and global climate change. Acta Climatologica, 51-52: 7-35. https://doi.org/10.14232/acta.clim.2018.52.1

Dezsö, Zs., Rumpler, D., Pongrácz, R., Bartholy, J., 2018: Felszínhőmérsékleti mérések Budapest XI. kerületében. In: Pongrácz R., Mészáros R., Kis A. (szerk.) Aktuális környezeti problémák az időjárás és az éghajlat összefüggésében. Egyetemi Meteorológiai Füzetek, 30: 43-50. https://doi.org/10.31852/EMF.30.2018.043.050

Oke, T.R., 1982: The energetic basis of the urban heat island. Quarterly Journal of the Royal Meteorological Society, 108(455): 1-24. https://doi.org/10.1002/qj.49710845502

Pieczka, I., Pongrácz, R., Bartholy, J., Szabóné André, K., 2018: Future temperature projections for Hungary based on RegCM4.3 simulations using new representative concentration pathways scenarios. International Journal of Global Warming, 15: 277-292. https://doi.org/10.1504/IJGW.2018.093121

Pongrácz, R., Bartholy, J., Pieczka, I., Szabóné André, K., 2016: RegCM szimulációkon alapuló éghajlati becslések eredményei. In: Kutatási és operatív feladatok meteorológusként. Az ELTE Meteorológus TDK 2016. évi Nyári Iskola elöadásának összefoglalói. (Pongrácz R., Mészáros R., Kis A. szerk.) Egyetemi Meteorológiai Füzetek, 27: 125-133. https://doi.org/10.31852/EMF.27.2016.125.133

Stewart, I.D., Oke, T.R., 2012: Local climate zones for urban temperature studies. Bulletin of the American Meteorological Society, 93(12): 1879-1900. https://doi.org/10.1175/BAMSD-11-00019.1

Szalai, S., Auer, I., Hiebl, J., Milkovich, J., Radim, T. Stepanek, P., Zahradnicek, P., Bihari, Z., Lakatos, M., Szentimrey, T., Limanowka, D., Kilar, P., Cheval, S., Deak, Gy., Mihic, D., Antolovic, I., Mihajlovic, V., Nejedlik, P., Stastny, P., Mikulova, K., Nabyvanets, I., Skyryk, O., Krakovskaya, S.,Vogt, J., Antofie, T., Spinoni, J., 2013: Climate of the Greater Carpathian Region. Final Technical Report. www.carpatclim-eu.org 
Dezső Zs., Bartholy J., Pongrácz R.:

Természetes és mesterséges városi burkolatok felszínhőmérsékleti viszonyai Budapest XI. kerületében

Internetes hivatkozások

KSH, 2019: https://www.ksh.hu/docs/hun/xstadat/xstadat_eves/i_wdsd001.html

\section{ORCID}

Dezső Zs. (D) https://orcid.org/0000-0003-1325-1303

Bartholy J. iD https://orcid.org/0000-0002-3911-7981

Pongrácz R. (D) https://orcid.org/0000-0001-7591-7989 